\title{
EPOR wt Allele
}

National Cancer Institute

\section{Source}

National Cancer Institute. EPOR wt Allele. NCI Thesaurus. Code C51351.

Human EPOR wild-type allele is located within 19p13.3-p13.2 and is approximately $7 \mathrm{~kb}$ in length. This allele, which encodes erythropoietin receptor protein, is involved in the activation of several different intracellular pathways including: Ras/MAP kinase, phosphatidylinositol 3-kinase and ST AT transcription factors. The allele also plays a critical role in erythroid cell survival. 